Kevin M. Vander Schel

Gonzaga University

DOI: 10.15290/std.2017.03.14

\title{
ERICH PRZYWARA ON JOHN HENRY NEWMAN AND THE SUPERNATURAL
}

\begin{abstract}
This essay inquires into the unique intersection of Erich Przywara and John Henry Newman and explores the re-imagined notions of divine transcendence and the supernatural in their works. Przywara found in Newman a source of inspiration for a more lively presentation of Catholic thought and a model for illuminating the path toward a new Catholic intellectual culture. Newman's work highlights the actively inquiring disposition of faith, an active search for the meaning of its doctrines, a progressive and unceasing journey that comprises the entirety of one's life. By showing the changing Catholic responses to modernity and the evolving theological approaches that would come to characterize later twentieth-century Catholic thought, the paper emphasizes how Przywara and Newman contributed to a more vibrant form of Catholicism and a renewal of Catholic intellectual culture that anticipated the Church's wider opening to the world..
\end{abstract}

Key words: Przywara, Newman, Rahner, supernatural, Neo-Scholasticism.

"[Przywara] stands at a place in the road that many in the Church have yet to get past."

Karl Rahner

K. Rahner, Gnade als Freiheit. Kleine theologische Beiträge (Freiburg: Herder, 1968), 272; quoted in E. Przywara, Analogia Entis: Metaphysics: Original Structure and Universal Rhythm, trans. J. R. Betz and D. B. Hart (Grand Rapids, MI: Eerdmans, 2014), 5. H. Urs von Balthasar likewise laments, "our age has chosen the easier path of not engaging 
"My unchangeableness here below is a perseverance in changing."

John Henry Newman

One of the notable features of the resurgence of German Catholicism in the 1920s is the curiously far-reaching interest in the writings of the English Cardinal John Henry Newman. For many Catholic intellectuals seeking more open and dynamic expressions of their faith in this period, Newman's work held multifaceted appeal. His public and controversial conversion from the culturally dominant Church of England to the seemingly foreign world of Catholicism resonated with the experience of many German scholars entering the Church after the First World War. ${ }^{3}$ His essays and sermons furthermore depicted a vibrant form of Catholic thought that seemed to stand beyond the impasse between scholasticism and modernism. Many were also attracted to Newman's dialectical and disarming style and his relentless dedication to the pursuit of truth in matters of faith. Not unlike Kierkegaard, whose works enjoyed a similar renaissance in this period, Newman offered a fresh voice that spoke to new challenges for Catholic belief in the rapidly shifting political, social, and intellectual climate of the time. His writings presented refreshingly agile and suggestive treatments of thorny issues such as divine transcendence and historical development, the elusive certitude undergirding religious conviction, and the hiddenness of the supernatural in the everydayness of ordinary life.

The Silesian Jesuit priest Erich Przywara was among Newman's early admirers in Germany. Przywara encountered Newman's thought during the closing years of his doctoral study, prior to his ordination in 1920. Shortly thereafter, he began a coordinated effort to produce a German translation of Newman's

him." See Balthasar, Erich Przywara, in Tendenzen zur Theologie im 20. Jahrhundert. Eine Geschichte in Porträts (Stuttgart: Olten, 1966); quoted in Analogia Entis, 8.

2 See J. H. Newman, Meditations and Devotions of the Late Cardinal Newman (New York: Longmans, Green, 1893), 508-09. This phrase was frequently mentioned by Przywara. See E. Przywara, Gottgeheimnis Der Welt: Drei Vorträge über die Geistige Krisis der Gegenwart, in Schriften, vol. 2 (Eisiedeln: Johannes-Verlag, 1962), 241; quoted in K. L. Johnson, Karl Barth and the Analogia Entis (New York: T\&T Clark, 2010), 38.

3 On the relation of Newman's reception in Germany to the conversions to Catholicism during the postwar years, see H.-B. Gerl-Falkovitz, 'His Whole Life Consisted of a Search for Religious Truth': Edith Stein in Conversation with John Henry Newman, in Contemplating Edith Stein, ed. J. A. Berkman (Notre Dame, IN: Univ. of Notre Dame Press, 2006), 149-58; see also G. Biemer, Theodor Haecker: In the Footsteps of John Henry Newman, New Blackfriars 81 (2000): 412-31. 
principal writings, working concurrently with other scholars such as Theodor Haecker and Romano Guardini, and in 1922 he published an eight-volume critical selection from Newman's collected works. ${ }^{4}$ In Newman, Przywara found a source of inspiration for a more lively presentation of Catholic thought and a model for illuminating the path towards a new Catholic intellectual culture. He hailed Newman as a church father for modern Christianity and praised his calm balance and his "secure step" in navigating the extreme subjectivism and rationalism that beset modern theology and philosophy. ${ }^{5}$ Newman, for Przywara, seemed to speak from the concrete experience of vital faith, and to possess a rare sense for the Ignatian principle of "finding God in all things."

This essay inquires into the unique intersection of these two modern Catholic thinkers and explores the re-imagined notions of divine transcendence and the supernatural in their works. Both Newman and Przywara departed from abstract and static conceptions of nature and the supernatural to affirm the abiding presence of God amidst the challenges and oppositions that characterize ordinary human living. And Przywara takes up Newman's thought in order to distinguish a foundational Catholic principle and a unifying vision for German Catholicism, discerning the hiddenness of God within the rhythms and tensions of finite life. Attention to the unique interconnection between these thinkers sheds light on the developing contours of the emerging Catholic intellectual life in this period and clarifies an important line of influence in twentieth-century Catholic thought.

\section{Between Neo-Scholasticism and Modernism}

Despite their clear differences in context, the writings of Newman and Przywara share an underlying relation to two significant moments in modern Catholic theology: the rise of neo-scholasticism and the emergence of Catholic

$4 \quad$ See J. H. Newman, Christentum. Ein Aufbau, 8 vols., trans. O. Karrer (Freiburg: Herder, 1922). Przywara presents his analysis and approach to the compilation in the fourth volume, entitled Einführung in Newmans Wesen und Werk. For a English translation of Przywara's arrangement, though without his own introductory remarks and summary, see J. H. Newman, The Heart of Newman (San Francisco: Ignatius Press, 1997). Several groups of scholars worked independently on German translations of Newman's writings in the early 1920s, at times producing competing translations. Translation projects were undertaken by Przywara, who had enlisted the help of Edith Stein; Maria Knoepfler, who enjoyed support from Josef Weiger and Romano Guardini; Theodor Haecker; and Matthias Laros. On the complicated history of Newman's postwar reception in Germany, see Gerl-Falkovitz, His Whole Life Consisted of a Search, 151-55; see also Przywara, Analogia Entis, 14.

5 See E. Przywara, St. Augustine and the Modern World, trans. E. I. Watkin, in St. Augustine: His Age, Life, and Thought (New York: Meridian Books, 1964), 283. 
Modernism. Neo-scholasticism had its roots in the revival of medieval and Thomistic philosophy and theology that began in the 1840s. Together with the growing movement of Ultramontanism, which aimed to centralize ecclesial authority in the papacy, this return to medieval thought sought to stem the tide of secularism, doubt, and "liberalism" that had spread into Catholic thought and practice in the mid-nineteenth century. ${ }^{6}$ Though wide-ranging in their interests, neo-scholastic theologians displayed a common concern to defend the possibility of the supernatural against Enlightenment forms of rationalism and skepticism, which threatened to erode certitude in the Church's established teachings. Thinkers of this school sought to articulate a perennial philosophy that could demonstrate the permanent compatibility of Catholic doctrine with the principles of sound reason, and they sharply distinguished between truths belonging to the order of nature and those dependent upon supernatural revelation and divine grace. During the late nineteenth century, this neo-scholastic approach would become firmly entrenched in Catholic thought. The condemnation of liberal views in the 1864 Syllabus of Errors, along with the First Vatican Council's promulgation of papal infallibility in 1870, helped solidify a lasting opposition to modern philosophical and social thought and cast suspicion upon any theological work that would attempt some accommodation to modern trends. The neo-scholastic movement moreover received official sanction in 1879 through Pope Leo XIII's encyclical Aeterni Patris, which looked to restore the philosophy of Thomas Aquinas as the proper foundation for all Catholic theological teaching. ${ }^{\text {? }}$

In the Modernist controversy of the late nineteenth and early twentieth centuries, however, the concern for greater dialogue with modern intellectual and social currents would resurface. The term "Modernism" itself designates no single unified theological system or specific school of thought. Instead, it refers to a general movement among a relatively small group of Catholic intellectuals, working roughly during the years 1890-1910, who desired a more sincere engagement with the developments of modern thought, especially in regards to the experiential dimension of faith, the relation of knowledge and

6 This neo-scholastic school did not then represent a simple recovery of Aquinas but rather appropriated Aquinas's thought to defend the faith from the challenges of modernity. See J. C. Livingston, Modern Christian Thought, vol. 1: The Enlightenment and the Nineteenth Century (Minneapolis: Fortress Press, 2006), 342-55.

7 This school of thought would remain the dominant form of theological and seminary education throughout the early twentieth century, as the 1917 Code of Canon Law formalized the study of Aquinas's thought as the foundational curriculum in all institutes of higher education. See J. C. Livingston, F. Schüssler Fiorenza et al., Modern Christian Thought, vol. 2: The Twentieth Century (Minneapolis: Fortress Press, 2000), 197. 
belief, and the use of historical criticism in biblical interpretation. ${ }^{8}$ The name itself was a derogatory label invented by those opposed to this tendency, and it was used to characterize a diverse collection of writers and scholars such as Maurice Blondel, Alfred Loisy, Edouard Le Roy, Friedrich von Hügel, and George Tyrell. These thinkers worked independently, writing on a wide range of topics within philosophy and theology, and at times sharply disagreeing with one another. Nonetheless, their interests broadly converged on issues of historical development, apologetics, and a concern to balance the one-sided emphasis on divine transcendence with an account of the "immanence" of faith in the dynamism of human consciousness and the strivings of the human heart. In the words of the English Jesuit George Tyrell, belief in divine revelation is not a mere matter of rationally assenting to supernaturally-revealed truths but involves "a complex spiritual experience ... made up of feelings and impulses and imaginings; which reverberates in every corner of the soul and leaves its impress everywhere..."

The Church's official objection to Modernism centered on this principle of "vital immanence," arguing that it ended in a reductive "agnosticism" that denied the genuine reality of the supernatural. ${ }^{10}$ Against the reform-minded Modernist thinkers, the Church put forward an "integralist" position, defending Catholic orthodoxy as a unified and interconnected body of divinely-given truths that was threatened by modification of any of its individual parts. The movement was formally condemned in 1907 by Pius X's encyclical Pascendi dominici gregis, which once again asserted the primacy of Thomistic philosophy in Catholic thought. The further institution of an anti-modernist oath in 1910, made necessary for all candidates for the priesthood, effectively ended any sense of Modernism as an identifiable movement, though the myth of an underlying Modernist threat would persist generations. ${ }^{11}$

8

See J. C. Livingston, Modern Christian Thought, vol. 1, 364-80.

G. Daly, Transcendence and Immanence: A Study in Catholic Modernism and Integralism (Oxford: Clarendon Press, 1980), 160. As Daly notes, "The term 'modernist' is inescapably imprecise" (5). Yet some, such as George Tyrell, also accepted the name as a fitting label, as designating "a churchman, of any sort, who believes in the possibility of a synthesis between the essential truth of his religion and the essential truth of modernity" (4).

See G. Daly, Transcendence and Immanence, 1-6, and 166-89. Many critics of "modernist" theology also focused on the dangers of neo-Kantianism and presented Aquinas as the proper antidote to Kant's subjective philosophy.

See J. C. Livingston, Modern Christian Thought, vol. 1, 378-79; and G. Daly, Transcendence and Immanence, 218: "The term 'modernist' remained as a convenient label for any theological initiatives ... which appeared to deviate from the neo-scholastic norm, especially in matters of dogma, biblical criticism, and Church polity." 


\section{Newman's Disputed Legacy}

Newman's own work likewise sought to properly respond to modern intellectual and social challenges. However, his unique contributions to Catholic thought largely stood apart from these broader theological movements; his writings aligned neither with his neo-scholastic contemporaries nor with the works of later Modernists. Like many churchmen of his day, Newman wrote against the dangers of liberal skepticism and the narrow rationalism that followed in the wake of the Enlightenment. Upon his appointment as a Cardinal in 1879 , he named this opposition to liberalism a unifying theme of his work overall. ${ }^{12}$ Yet he also showed little enthusiasm for the resurgent Thomistic philosophy of his day. Although he wrote widely and at a prolific pace, he kept a distance from neo-scholastic disputes, preferring instead to engage the works of classical and patristic theologians. ${ }^{13}$ And although his conversion from champion of the Oxford Movement to loyal son of the Church was wellreceived, as a kind of public triumph, many of his major writings quickly fell into disfavor with officials in Rome. His Essay on the Development of Christian Doctrine (1845), which played a decisive role in his own transition to Catholicism, aroused particular suspicion, with neo-scholastic critics excoriating his characterization of Christianity as a living, historically-developing idea and some seminary instructors in Rome mining the text to present examples of heresy to their students. ${ }^{14}$ His later Essay in Aid of the Grammar of Assent (1870) similarly drew objections for its seemingly "subjectivist" tendencies, which might endanger the proper certitude of belief. ${ }^{15}$ Additionally, while

12 As Paul Misner argues, however, Newman's own understanding of liberalism was more narrowly directed towards Benthamite tradition of instrumental reason. See P. Misner, The 'Liberal' Legacy of Newman, in Newman and the Modernists, ed. M. J. Weaver (New York: Lantham, 1985), 3-4. See also O. Chadwick, Newman: A Short Introduction (New York: Oxford Univ. Press, 2010), 71-76.

13 Indeed, following his 1845 conversion, during his neo-scholastic education in Rome, Newman reports falling asleep during the lectures on dogmatics and morals. See S. Gilley, Newman and His Age (London: Darton, Longman, and Todd, 1990), 249. On Newman's cautious reaction to the impersonal neo-scholastic theology of his day, see G. Daly, Newman, Divine Revelation, and the Catholic Modernists, in Newman and the Word, ed. T. Merrigan and I. T. Ker (Paris: Peeters, 2000), 55-58; and J. Cornwell, Newman's Unquiet Grave (London: Continuum, 2010), 99-100.

14 The Jesuit theologian Giovanni Perrone, for example, who would later befriend Newman and defend his orthodoxy, was initially highly critical of the piece, writing that Newman mixed up and confounded everything - "Newman miscet et confundat omnia." See S. Gilley, "Life and Writings," in The Cambridge Companion to John Henry Newman (New York: Cambridge Univ. Press, 2009), 14-18, at 15. 
upholding the authority of the pope, Newman remained critical of extreme forms of Ultramontanism, arguing that the definition of papal infallibility was "inopportune" and unnecessary and pointing to the consensus of the lay faithful as another infallible "voice" of the Church. ${ }^{16}$

In this regard, Newman's writings occupied a curious position in nineteenthcentury Catholic thought. His own inquiries into historical development and the lively interplay of faith, imagination, and understanding had led him to a conviction of the truth of the Catholic Church's teachings, yet the Church itself was waging an increasingly forceful campaign to present its teachings as fixed, objective, and not open to further development. While remaining devoted to the authority of the Church, Newman was thus in an important respect out of place in its theological climate: he served to represent a Catholicism that was not defined by scholasticism. ${ }^{17}$ His precarious situation was aptly described by his fellow Oratorian Ignatius Ryder, who wrote that with Newman's conversion officials in Rome recognized that they had gained "a formidable engine of war on their side, but they were distinctly aware that they did not thoroughly understand the machinery [and] they came to think, some of them, that it might perhaps one day go off of itself or in the wrong direction." 18

In light of this uneasy relationship with the prevailing theological currents of his day, it may be tempting to see Newman as a forerunner for later Modernist thinkers. Indeed, he was later branded the "father of Modernism," and several notable Modernists cited Newman's work as an important influence upon their own, especially in regards to questions of doctrinal development and the role of inner experience in preparation for faith. ${ }^{19}$ However, in several important respects Newman's views also differed from the positions of the more prominent figures within the Modernist movement. Despite his sharp criticisms of the push towards papal infallibility, for example, he maintained

16 See I. Ker, Newman on the 'Consensus Fidelium' as 'The Voice of the Infallible Church', in Newman and Word, 69-90.

17 See Oliver Rafferty's introduction in George Tyrell and Catholic Modernism, ed. O. P. Rafferty (Portland, OR: Four Courts Press, 2010), 12-13.

18 Quoted in Andrew Pierce, Crossbows, Bludgeons and Long-range Rifles: Tyrell, Newman, and 'The Intimate Connection between Methods and their Results', in George Tyrell and Catholic Modernism, 60. On the other hand, the influence of Newman's writings in England and his symbolic role in leading later English converts to the Church was well-appreciated (65-70).

19 See J. C. Livingston, Modern Christian Thought, vol. 1, 364-76; and Przywara, "Zur Geschichte des 'modernistischen' Newman," Stimmen der Zeit 102 (1922): 443-51. Przywara traces Newman's mistaken reputation as a modernist to two studies by Alexander Whyte and Dean Church. 
that theologians must defer to the judgment of the pope and the bishops, and in the end he gave the council his qualified support. Moreover, his discussions of the teachings, offices, and vocation of the Church, while often significantly more subtle and nuanced than those of his neo-scholastic peers, still accorded with many points of the later "integralist" position, affirming the interconnection and inner coherence of Catholic teaching as a whole. This point was not lost on the Modernists, who struggled to reconcile Newman's deep respect for orthodoxy and authority with his seemingly radical and decidedly non-scholastic ideas. ${ }^{20}$

As this brief summary indicates, the question of Newman's legacy quickly became a disputed one. In the decades following his death in 1890, thinkers would offer varying and competing interpretations of his thought, and his work on the development of doctrine and the role of conscience in the religious life would continue to stimulate fruitful reflection and lively debate among later Catholic theologians. ${ }^{21}$ In view of his later appeal in Germany, however, two closely-related areas of his thought deserve specific mention: the intersection of faith and reasoning, and his treatment of the supernatural.

\section{Newman on Reasoning in Belief}

While remaining circumspect in response to the neo-scholastic theology of his time, Newman nonetheless offered a pointed rejection of impersonal and disputational approaches to theology overall. His writings and sermons consistently opposed the prevailing attitude of theological rationalism, according to which no personal preparation or activity in faith was needed to assent to Christian doctrine. One of the principal errors of the age, in his view, was the insistence on the need for disinterested or impartial reasoning in matters of faith, by which a person's philosophical or theological convictions are separated from one's character, dispositions, and desires. ${ }^{22}$ "Is not this the error," he asks in his University Sermons, "the common and fatal error, of the world, to think itself a judge of religious truth without preparation of heart? ... But in the schools of the world the ways towards truth are considered high roads open to all [persons], however disposed, at all times. Truth is to be approached

$20 \quad$ See S. Gilley, Life and Writings, 26-28; and A. Pierce, Crossbows, Bludgeons and Long-range Rifles, 63-68. On the relation of Newman and the Modernist movement, see Newman and the Modernists, especially 185-208.

21 On the centrality of conscience within faith, see G. Hughes, Conscience, in The Cambridge Companion to John Henry Newman, 189-220.

22 See S. Gilley, Newman and His Age, 55-56. 
without homage..." ${ }^{23}$ His later Grammar of Assent proffers a similar critique, in response to the Anglican theologian William Paley's apologetic work Evidences of Christianity:

I say plainly I do not want to be converted by a smart syllogism; if I am asked to convert others by it, I say plainly I do not care to overcome their reason without touching their hearts ... [Persons] are too well inclined to sit at home, instead of stirring themselves to inquire whether a revelation has been given; they expect its evidences to come to them without their trouble; they act, not as suppliants, but as judges ...24

In contrast to this rationalistic approach, Newman's work highlights the actively inquiring disposition of faith. Real assent in matters of belief, as opposed to the notional assent given to abstract ideas, is living, dynamic, and personal. It is characterized by an imaginative wonder that moves one to action. As Newman writes,

A religious mind is ever marveling, and irreligious [persons] laugh and scoff at it because it marvels. A religious mind is ever looking out of itself, is ever pondering God's words... Carnal and proud minds are contented with self; they like to remain at home; when they hear of mysteries, they have no devout curiosity to go and see the great sight... and when it actually falls in their path, they stumble at it. ${ }^{25}$

Faith, for Newman, is thus not opposed to reason but rather frames a particular habit of mind. In regards to questions of belief, morality, and personal identity, human reasoning has an inescapably fiduciary character, as values and prior assents shape both one's questions and one's openness to the evidence. In this sense, faith marks the manner of reasoning in a religious mind. ${ }^{26}$

Accordingly, faith designates no passive acceptance of the Church's established teachings but an active search for the meaning of its doctrines, a progressive and unceasing journey that comprises the entirety of one's life. Likewise, genuine religious conviction, in Newman's view, does not simply follow from a disinterested apprehension of strict logical necessity or abstract proof but emerges from the subtle and unobtrusive "accumulation of various probabilities" in one's concrete personal living. ${ }^{27}$ Hence, with regard to one's belief in the existence of God, he writes, "[i]t is not so much proved to him,

23 J. H. Newman, Fifteen Sermons Preached Before the University of Oxford (London: Longmans, 1898), 198-99.

24 Idem, An Essay in Aid of a Grammar of Assent (London: Longmans, 1903), 425.

25 Idem, Parochial and Plain Sermons, vol. 4 (London: Longmans, 1909), 293.

26 See D. Burrell, Newman in Retrospect, in The Cambridge Companion to John Henry Newman, 256.

27 J. H. Newman, Grammar of Assent, 411. 
as borne in upon his mind irresistibly, as a truth which it does not occur to him, nor is possible for him, to doubt ... He cannot unravel the process, or put his finger on the independent arguments, which conspire together to create in him the certainty which he feels." 28 The certitude of Christian belief then is not a product of the "rude operation of syllogistic treatment"; it arises "by arguments too various for direct enumeration, too personal and deep for words, too powerful and concurrent for refutation." ${ }^{29}$ Moreover, Newman insists, this manner of gaining certainty in faith is not exceptional but represents the "normal condition of human nature" and the ordinary mode of human reasoning in concrete matters. ${ }^{30}$

In this respect, Newman's analysis of the rationality of belief strikes a notably Augustinian note, appealing not to the demonstrations of formal logic but attending to the nuances of his own reasoning. He presents the revelation of Christian faith not as an immutable, received collection of propositions, but a living, real idea that takes root and grows in the body of the Christian faithful.

\section{Newman on the Life of Grace}

Alongside this unique account of the interconnectedness of faith and reason, Newman's writings portray a close integration of nature and grace. In contrast to prominent neo-scholastic views that pressed for a clean distinction between the orders of nature and the supernatural, Newman describes supernatural grace neither as an extrinsic reality added to human nature nor a special divine aid that steps in when ordinary human activity reaches its limit but as a reality subtly present to the entirety of human living.

Thus, in his writings on faith and justification, Newman avoids any neat division of the spiritual life into supernatural moments owing to God's grace and natural moments belonging to human initiative. Instead, he points to God's grace as permeating and informing every aspect of belief and action, and as taking up and weaving together the various strands of conscious human living. He describes the justification or salvation of believer by grace as centered in the indwelling of the Spirit in the human person. ${ }^{31}$ Yet he also

\footnotetext{
28 J. H. Newman, Discourses to Mixed Congregations (London: Longmans, 1906), 261.

29 Idem, Grammar of Assent, 288, 492.

30 Ibidem, 492.
}

31 Newman consistently speaks of the triune God present in the believer, yet he describes this presence of God to the human person in various ways, as for instance "the indwelling of the Trinity," "the indwelling of Christ," "the indwelling of the Holy Spirit," or "the indwelling of Christ through the Holy Spirit." See, for example, J. R. Connolly, The Indwelling of the Holy Spirit and D. Nussberger, Marked by Christ's Presence: Newman's 
indicates this unique and personal "inward gift" of God's presence as a reality that cannot be adequately captured in doctrinal formulas or located within a specific human habit but only accepted in one's life and expressed in one's action. 32 "Justification," he writes, "...consists in God's inward presence, and lives in obedience." 33

In this fashion, Newman depicts divine grace as effecting a pervasive renewal in conscious human life, which gradually transforms one's character and reorients one's manner of living. Yet this grace works quietly and unobtrusively. It does not remove one from the realities of ordinary life, but yields a simple openness to God and an active love for others expressed amidst the tasks of mundane, daily living. ${ }^{34}$ Genuine holiness, Newman insists, is marked by the signs of simplicity, peace, and calmness, and the perfection in Christian life is not to be found in an otherworldly mystical flight but is simply "to perform the ordinary duties of the day well" and to recognize the unseen presence of God in all things of this world. ${ }^{35}$

\section{Newman and the Przywara Phenomenon}

Newman's rich and suggestive theological approach quickly proved attractive to the succeeding generation of Catholic thinkers. By the turn of the twentieth century, his works had become a regular source of inspiration for English and French theologians seeking a more adequate account of the experiential basis of faith and religious knowledge. During the 1920s, Newman's work also came to exercise significant appeal in Germany, where his

Incarnational Spirituality, in Newman E Life in the Spirit, ed. J. R. Connolly and B. W. Hughes (Minneapolis: Fortress Press, 2014), 31-50, 113-28. This indwelling presence of God is central to Newman's mature understanding of justification. See, in this same volume, J. R. Connolly, Newman's Vision of Holiness in This World, 157, n. 83; and T. L. Sheridan, Justification, in The Cambridge Companion to John Henry Newman, 98-117.

32 K. Mongrain, Newman and the Spirituality of the Oratory, in Newman Eु Life in the Spirit, 194-95. In this respect, as John Connolly writes, Newman sets aside impersonal views of grace: "Grace is not a thing, but a personal relationship." See Connolly, The Indwelling of the Holy Spirit, 44.

33 T. L. Sheridan, Justification, 112, italics original.

34 As Kevin Mongrain notes, Newman describes the "slow, quiet aid of divine grace that works more like 'dew drops on the grass' than a flood." See K. Mongrain, Newman and the Spirituality of the Oratory, 191.

35 J. H. Newman, Newman the Oratorian: Oratory Papers (1846-1878), ed. P. Murray (Herefordshire, UK: Gracewing, 2004), 359; quoted in Mongrain, Newman and the Spirituality of the Oratory, 196; see also Connolly, Newman's Vision of Holiness in This World, 145-66. 
uniquely personal style gained him a reputation as a sincere religious thinker who passionately engaged the pressing difficulties of modern belief. ${ }^{36}$

Newman's reception in the interwar period occurred within the context of a broader revival of German Catholicism. The years after the First World War saw numerous conversions, the emergence of liturgical and religious youth movements, a rapid growth of creative works in theology and philosophy of religion, and a growing enthusiasm for recovering the "Catholic spirit as a creative component of contemporary intellectual life." ${ }^{37}$

This emerging "springtide" of Catholicism in Germany also coincided with the "Przywara phenomenon." 38 Przywara, a Jesuit trained in scholastic thought yet also a voracious reader of patristic theology and German idealist philosophy, played a central role in this renewal of Catholic interest and, together with figures such as Romano Guardini and Karl Adam, became a leading voice of Catholic intellectuals in the 1920s and 1930s. He quickly gained recognition for his bold and wide-ranging philosophical commentary and his incisive criticisms of contemporary intellectual and cultural movements. His Gottgeheimnis der Welt (God as the Mystery of the World) (1923) and Ringen der Gegenwart (The Present Struggle) (1929) presented collections of timely critical essays from 1922-27, which treated the pressing theological, literary, and cultural debates of the day. While never occupying a professional academic post, he also served as editor of the well-respected Jesuit journal "Stimmen der Zeit" (Voices of the Time) from 1922 until its forced closing by the Gestapo in 1941, a position which provided him both with intellectual freedom and a public forum for developing his innovative views through essays, regular lectures, and lengthy book reviews. ${ }^{39}$

36 Such was the impression shared by both Edith Stein and Theodor Haecker. See GerlFalkovitz, His Whole Life Consisted of a Search, 155; and Biemer, Theodor Haecker: In the Footsteps of John Henry Newman, 417-20.

37 Gerl-Falkovitz, His Whole Life Consisted of a Search, 156. In addition to the Stein, Haecker, and Dietrich von Hildenbrand, converts included other notable figures such as Gertrud von le Fort, Hugo Ball, and Ruth Schaumann. On the increased conversions in this time, see Przywara, Konvertiten, in Ringen der Gegenwart: gesammelte Aufsätze 1922-27, vol. 1 (Augsburg: B. Filser-Verlag), 1929), 146-54; and T. F. O’Meara, Erich Przywara, S.J.: His Theology and His World (Notre Dame, IN: Univ. of Notre Dame Press, 2002), $42-45$.

38 Gerl-Falkovitz, His Whole Life Consisted of a Search, 157. Przywara and Edith Stein both evoked the language of a new, holy springtime for Catholicism in Germany. Newman famously drew on this imagery in his 1852 address Second Spring, on the survival and the looked-for resurgence of Catholicism in England after the English Reformation. See Cornwell, An Unquiet Grave, 138-39.

39 See T. F. O'Meara, Erich Przywara, S.J., 3-14. 
Przywara's "meteoric rise" to prominence during the 1920s was due in part to his considerable skill in articulating and responding to the wide-ranging philosophical controversies and cultural crises of the period. ${ }^{40}$ Through essays and monographs, he weighed in on a diverse array of intellectual movements - such as phenomenology, Thomism, neo-Kantianism, liberal Protestantism, and the dialectical theology of Karl Barth - treating each with discerning nuance and interpretative generosity. These studies won him a reputation among his contemporaries as a skilled constructive critic and a pioneering "witness to his time." ${ }^{41}$ His influence was also no doubt aided by his startlingly prodigious energy and remarkable productivity. Though his writing would slow after the outbreak of the Second World War due to illness and repeated bouts with anxiety, prior to his death in 1972 he authored more than eight hundred articles and reviews and over forty monographs, in addition to performing regular priestly duties and offering frequent lectures. ${ }^{42}$

Yet Przywara's influence is also owed to his unique vision of Catholicism in the modern world. Throughout his writings, Przywara saw a role for a positively creative and culturally open form of Catholicism. ${ }^{43} \mathrm{He}$ spoke of a new sort of Catholic thinking, one lying beyond the antithesis of modernism and integralism, which could illuminate the dull everydayness of ordinary life by uncovering a deeper ethos and a vibrant spirituality that engaged present intellectual and social challenges. His works presented no fixed or overarching speculative system but sketched a flexible framework for bringing theological insights into critical engagement with contemporary philosophy, history, and culture. Throughout various essays and articles, he points to the tensions of life and the ongoing struggles of the age as the very setting in which one

$40 \quad$ F. Wulf, Christliches Denken. Eine Einführung in das theologische-religiöse Werk von Erich Przywara, S.J. (1889-1972), in Gottes Nähe, ed. P. Imhof (Würzburg: Echter, 1990), 364; quoted in O'Meara, Erich Przywara, S.J., 2.

41 K. Neufeld, Kategorien des Katholischen. P. Erich Przywara - 100 Jahre, in Catholica 43, no. 2 (1989): 295; cited in O'Meara, Erich Przywara, S.J., 3. See also Neufeld, Kategorien des Katholischen, 297: "Przywara stepped forward as the analyst of the moment; more precisely, as the examiner of spiritually and culturally influential streams of the moment ... He belongs to the pioneers of a conscious and encompassing analysis of the age." Commentators of the time likewise praised Przywara's intellectual charity, describing him as "the most important intellectual phenomenon in realm of contemporary German Catholicism" and as "Germany's greatest constructive critic in philosophy." See Przywara, Analogia Entis, 16.

42 John Betz reports that in the years spanning from 1922-32, Przywara authored 230 articles and book reviews and 17 books, while also giving 237 lectures. See Przywara, Analogia Entis, 15; see also Johnson, Karl Barth and the Analogia Entis, 34, n. 76. On Przywara's later illness, see O'Meara, Erich Przywara, S.J., 13-14. 
discerns and describes God. In an image provided by the Catholic theologian Hans Urs von Balthasar, Przywara's thought offered a kind of critical therapy to Catholic intellectuals of his day, playing the instrumental role of teaching his contemporaries "how to speak appropriately of God" in the parlance of modern thought. ${ }^{44}$

In his mature writings, Przywara describes this distinctively Catholic perspective through the principle of the analogia entis, a concept with origins in medieval Thomistic thought and a central category of neo-scholastic theology yet one that Przywara invests with novel and somewhat idiosyncratic meaning. Beyond its function as a logical rule or linguistic concept, he saw analogy as a foundational thought-form capable of mediating between the modern extremes of excessive subjectivism and speculative rationalism. The analogy of being, for Przywara, distinguishes the "basic law" (Grundgesetz) of Catholic thought and the "fundamental Catholic form. ${ }^{\text {" }}$ "It signals the recognition of God as always both "in" and "above" creation and the inescapable polarity of similarity and dissimilarity that obtains between God and creature. In "the self-communication of God reaching from creation to the human person," humanity expresses an indelible likeness to God, yet one in which the surpassing mystery of God remains ever distinct from the world and beyond the grasp of human systems. ${ }^{46}$

This understanding of the analogia entis provided Przywara a way of speaking of the mysterious movement of God in and through the patterns of history and culture, while resisting the one-sided tendencies in modern thought that would collapse God into the world or the world into God. It marks the "living unity-in-tension" (lebendige Spannungseinheit) between the poles of immanence and transcendence that frame the human relationship to God. ${ }^{47}$ Against the rigid distinction of nature and the supernatural, such analogy underscores their "inner unity" in the movement of historical living, through the various modes of human participation in God's supernatural redemptive work in the created world. ${ }^{48}$

$44 \quad$ U. von Balthasar, Erich Przywara, 357; quoted in Przywara, Analogia Entis, 7; see also J. V. Zeitz, S.J., Erich Przywara: Visionary Theologian, Thought 58 (1983): 151-55.

45 E. Przywara, Analogia Entis, 348; and Gerl-Falkovitz, His Whole Life Consisted of a Search, 162.

46 See Johnson, Karl Barth and the Analogia Entis, 36.

47 Ibidem, 41-42. In similar fashion, Przywara speaks of a "unity in duality." See E. Przywara, Polarity: A German Catholic's Interpretation of Religion, trans. A. C. Bouquet (London: Oxford Univ. Press, 1935), 81, 141ff.

48 E. Przywara, Analogia Entis, 349; J. V. Zeitz, Erich Przywara: Visionary Theologian, 145-48. 
Genuine Catholic spirituality, in Przywara's view, reflects this subtle principle throughout. The Catholic life finds at its center not a static equilibrium but a continual movement and change. Yet this movement of faith is not that of "a restless dissatisfied motion hither and thither" in an uneasy search for certainty, but a "dynamic rhythm" that is at home in the "living-concreteness" (Lebendig-Konkretes) of daily life. ${ }^{49}$

\section{Przywara on the Significance of Newman}

Przywara located the classical expression of this "Catholic middle" between transcendence and immanence in writings of St. Augustine. ${ }^{50}$ Yet in the modern period, he argues, it is Newman that most fully embodies this uniquely Catholic sense of balance. Like Augustine, Newman steers a middle course between the extremes of sentimentality, mysticism, and despair in the life of faith, displaying boldness yet also a tranquil self-possession. Przywara praises Newman's mature "poise" and his "mastery of the tension between the opposites" and antitheses of modern thought. ${ }^{51}$ In Newman alone, he writes, Augustine's spirit finds its "perfect reincarnation"; he is "the peculiar and unique Augustinus redivivus of modern times," who amidst the complexity and uncertainty of the age has his gaze calmly fixed upon the God who is all in all. ${ }^{52}$

This keen interest in Newman is notable as he largely stands outside the prevailing German philosophical tradition that runs through Kant, Schelling, and Hegel. For German Catholics looking to establish a new intellectual vision for Roman Catholicism, other candidates would appear closer to hand. Thinkers of the Catholic Tübingen school, for example, such as J. S. Drey, J. A. Möhler, or J. Kühn had also sought to articulate more vital forms of Catholic community

49 Idem, St. Augustine and the Modern World, 257. Przywara's language of rhythmic dynamism reflects his early studies of musical theory. On the importance of musical form for Przywara's later descriptions of polarity, unity-in-tension, and analogy, see Johnson, Karl Barth and the Analogia Entis, 33, n. 73.

$50 \quad$ Ibidem, 45; see also Przywara, Analogia Entis, 18 n. 58.

51 E. Przywara, St. Augustine and the Modern World, 283. In the preface to the first edition of his Analogia Entis (1932), Przywara likewise cites Newman's "dynamic antithetics" as an important influence. See Przywara, Analogia Entis, xx. Edith Stein and Theodor Haecker also noted this remarkable sense of balance and maturity in Newman, and Stein similarly praised Newman's multifaceted spirituality and "antithetical virtues." See Gerl-Falkovitz, His Whole Life Consisted of a Search, 155; and Biemer, Theodor Haecker: In the Footsteps of John Henry Newman, 418-22.

52 E. Przywara, St. Augustine and the Modern World, 279, 286. For Przywara, Newman especially exemplified the awareness of God's immanence, of God as "all in all." See Przywara, Polarity, 116; and Przywara, Christentum. Ein Aufbau, vol. 1, vi. 
and each wrote significant and discerning studies concerning nature and the supernatural..$^{53}$ Yet in Newman Przywara found a refreshing account of the foundation of religion, and one that appeared uniquely well-suited to the difficulties of modern belief. In his Essay on the Development of Christian Doctrine and his Grammar of Assent, Newman combined a deep historical awareness of Catholic thought with a rich psychological grasp of human consciousness and the experience of faith. With sober attentiveness to the concrete and dynamic aspects of Catholic tradition, he describes "how in real life one comes to receive the existence of God, comes to faith, and how faith in God and in revelation works itself out in personal life..." 54

Thus in Newman Przywara recognized the principle of the analogia entis at work. He embodied the precarious tension distinguishing genuinely Catholic spirituality, in the unwavering recognition of the "God Who is at once without and within." ${ }^{55}$ Newman's works, Przywara notes, highlight the way "the psychological and interior aspect of Christian living" is related to established Church dogma. ${ }^{56}$ Where Aquinas represented the pole of logical objectivity in belief, in the rational knowledge of creatures in their relation to God, Newman illuminates the personal and subjective pole of faith, in the concrete and living aspects of Christian existence. ${ }^{57}$

Przywara's interest in Newman moreover proved to be an abiding one. His work in organizing the 1922 collection of Newman's writings provided the catalyst for developing his own philosophy of analogy, and in the following decades Newman's thought provided a consistent guide and stimulus for his own writings. ${ }^{58} \mathrm{His}$ first major philosophical work on the foundation of religion (Religionsbegründung. Max Scheler - J.H. Newman) (1923) set out a critical analysis of Max Scheler's phenomenological approach through the lens of

53 For an overview of the themes and figures of the Catholic Tübingen school, see Livingston, Modern Christian Thought, vol. 1, 186-98.

54 E. Przywara, Zum Newmanschen Denktypus, in Jahrbuch des Verbandes der Vereine katholischer Akademiker zur Pflege der katholischer Weltanschauung (Augsburg: Verband der Vereine katholischer Akademiker, 1922), 147, 149; quoted in O'Meara, Erich Przywara, S.J., 88.

E. Przywara, St. Augustine and the Modern World, 279.

56 J. V. Zeitz, Erich Przywara: Visionary Theologian, 151.

57 See ibidem, 151-55; also Przywara, Polarity, 114-15. The choice, Przywara writes, is not between Thomas Aquinas or Newman but "true to the spirit of Catholic polarity, Thomas and Newman." See Przywara, Gottgeheimnis Der Welt, 242; quoted in Johnson, Karl Barth and the Analogia Entis, 42, n. 113.

58 See T. F. O’Meara, Erich Przywara, S.J., 86-88. 
Newman's theory of religious knowledge.${ }^{59}$ Newman's influence is also evident in Przywara's 1923 lectures Gottgeheimnis der Welt, which further refined his understanding of God's relationship to the world and the inescapable tension or polarity of the life of faith. And in a series of essays published in Ringen der Gegenwart, he highlights the freshness and contemporaneity of Newman's views while defending him against one-sidedly "Modernist" interpretations that overlooked his distinctive sense of balance. ${ }^{60}$

As Przywara notes, the significance of this "incipient German Newman movement" went beyond the mere recognition of Newman as a model for creatively engaging the modern world and highlighted a more fundamental problem in modern Catholic theology: that of adequately conceiving the relation between nature and the supernatural. ${ }^{61}$ His own work on analogy aims to make explicit the underlying structure behind this harmony-in-difference of nature and supernatural in the life of grace.

\section{Analogia Entis: "God in Us and God Above Us"}

Przywara presents the historical formula for analogy in a decree of the Fourth Lateran Council of 1215, which states that one cannot recognize "any similarity... however great" between God and God's creatures without also at the same time recognizing "an ever greater dissimilarity" between them. ${ }^{62}$ With this recognition of an enduring relation to God amidst an "ineradicable difference," he finds an underlying feature of the Catholic tradition as a whole, one which is most clearly evident in the work of Augustine and Thomas Aquinas. ${ }^{63}$ Analogy, he writes in his Analogia Entis (1932), is "the utterly fundamental

59 E. Przywara, Analogia Entis, 15, n. 51. This study criticizes Scheler's "essentialist" phenomenology, with its claims to a more immediate knowledge of God, in light of Newman's more balanced and indirect approach to faith and religious knowledge. See also O'Meara, Erich Przywara, S.J., 88-89.

60 In Gottgeheimnis der Welt, Przywara refers to Newman's recognition of the relation of transcendence and immanence in the tension of love and fear. See Przywara, Gottgeheimnis der Welt, 185-93; see also Przywara, Polarity, 114-15; and Przywara, Zur Geschichte des Modernistischen Newman, Stimmen der Zeit 102 (1922): 443ff.

E. Przywara, Analogia Entis, 348.

62 Ibidem, 355.

63 Ibidem, 354. Augustine and Aquinas offer two basic types of authentic Catholic theology: the Augustinian "transcending immanence" of the creature towards God, and the Thomistic "indwelling transcendence" of God toward the creature. See 419, 239. 
principle of Catholicism, because analogy is the utterly fundamental principle obtaining between God and creature." ${ }^{64}$

Przywara's characteristically dense writings in theology and philosophy of religion analyze this fundamental form of analogy at a high level of abstraction. In numerous essays and longer treatises, he repeatedly locates the theme of analogy within broader discussions of metaphysics, traces its development through various historical disputes, and contrasts it with approaches of his philosophical and theological contemporaries in the 1920s and 1930s. However, he treats the analogia entis not as a single philosophical formula or deductive rational principle but as a thoroughgoing Catholic language or style of thought, which points to human existence before God as always incomplete, continuing, and expanding. Such analogy offers no final resolution to the various dialectical oppositions of modern philosophy, nor does it suggest any mystical connection to the divine that allows one to sidestep the uncertainty and tension of human living. Instead, it signifies creaturely existence as a continuing process, one that is "never finished," remains fundamentally open, and is "ever new." 65

Przywara depicts this unfinished openness through a variety of suggestive and recurrent images. He describes it as a dynamic polarity, an interplay, "unityin-tension," "rhythm," an "oscillating relation," and a "suspended middle." ${ }^{66}$ As each of these descriptions makes clear, this analogical form culminates in no state of equilibrium or final harmony. On the contrary, against all "attempted escapes" from the tension of human life and thought, Przywara insists that God is encountered only in the "free hanging" and the "free suspendedness" of the analogia entis. ${ }^{67}$ At the same time, this in-between movement of analogy does not indicate absolute or unstructured change but discloses a deeper order or direction. It points beyond itself to what is "ever above-and-beyond," as the created world in its becoming bears an ineradicable orientation towards the

64 Ibidem, 362. Yet to Przywara this declaration also frames the Catholic response to the foundational metaphysical problem of the relation between essence and existence, which surfaces in the philosophical oppositions between infinity and finitude and transcendence and immanence as well as in the theological disputes of nature and the supernatural. Addressing such antitheses, Przywara notes, was a special focus of the various schools of German philosophy and theology of 1920s and 1930s. On these formal problems in western metaphysics, as well as Przywara's response to the various positions of his contemporaries, see 119-91, also his essay Philosophy as a Problem, 400-09.

65 Ibidem, 312.

66 Ibidem, 314, 422, 159, 67.

67 Ibidem, 429. 
mystery of God ${ }^{68}$ In this sense, analogy "is the formal law of 'religious experience' between the living God and the living human being." ${ }^{9}$

In Przywara's view, it is this analogical structure that offers the key insight into the problem of properly distinguishing and relating nature and the supernatural. ${ }^{70}$ It indicates the supernatural neither as a separate order of being set against the natural world, nor as a divine power that overwhelms the autonomy of human nature, nor again as an unearthly activity that periodically breaks into the created world from above. Instead, the concept of the supernatural signifies the manifold ways in which the ever-transcendent God is already present to and active within historical human living. It encompasses the full scope of God's ongoing redemptive work centered in Christ and the Church as well as the various modes of human participation in this higher spiritual life through grace. ${ }^{71}$ While resisting any identification of nature and supernatural, then, Przywara underscores their inseparability in religious experience, as they stand in close and constant integration in the one concrete order of salvation in human history. ${ }^{72}$

In this respect, Przywara develops his account of analogy in an innovative and original fashion. On one hand, he presents this principle as a retrieval and clarification of the fundamental mode of thought shared by all the greatest minds of the Catholic tradition. "In its objective form, and above all in my religious writings," he writes, "[analogy] was associated with the Augustinian formula "God in us and God beyond us."'73 On the other hand, following Newman, Przywara's inquiry into analogy aimed to provide a critical Catholic reflection on the growing challenges of modern thought. His works outline a vision of God and God's relationship to the world in which the divine mystery at the heart of Catholic faith animates the entirety of one's practical living yet remains ever hidden, eluding attempts at comprehension. ${ }^{74}$

68

69 Ibidem, 424.

$70 \quad$ Ibidem, 311, 363.

$71 \quad$ On the relation of the three components of "natural creatureliness," "supernatural participation in the divine nature," and "supernatural redemption," see ibidem, 364, n. 63; and 364-69; and compare 402-05.

72 This integration, he moreover insists, is not abstract and formal. It is visible in the reality of Christ, who is the "measure" between the incomprehensible God and the creation, and who continues to be manifest in the life of the Church. See ibid., 424-25, 532-36, 380-84. This Christological center came to play an increasingly important role in Przywara's later works.

73 Ibidem, 159-60.

74 See ibidem, 370-71. 


\section{Conclusion: Towards a New Catholicism}

Taken together, the writings of Newman and Przywara offer a unique glimpse into the changing Catholic responses to modernity and the evolving theological approaches that would come to characterize later twentiethcentury Catholic thought. Despite their separation in historical context and notable differences in style, both thinkers envisioned a more vibrant form of Catholicism and a renewal of Catholic intellectual culture that anticipated the Church's wider opening to the world. ${ }^{75}$ Their writings moved outside the reigning opposition of modernism and neo-scholasticism in late nineteenthand early twentieth-century Catholic theology, articulating a closer relation of nature and the supernatural that recognized the transcendence of God in the midst of the tensions and ambiguities of finite human living.

Przywara's appropriation of Newman's work also provides an important lens for appreciating the new directions emerging in German Catholicism in the interwar period. In Newman, he found inspiration for constructively engaging cultural trends and a model for navigating the intellectual and social crises of 1920s and 1930s. For Przywara, as for many Catholic intellectuals of the time, Newman's sincere inquiry into the life of faith and his attentiveness to the concrete and individual aspects of religious experience highlighted the need for a fresh mode of critical Catholic reflection, one that "makes the pulsating stream of the tradition perceptible for contemporary life."76

Taking up Newman's insights into the life of faith, Przywara presents a description of Catholic thought and practice marked not by the otherworldliness of an unchanging permanence but by its ceaseless movement and continuing growth. His writings present an important contribution in the growing attempts to chart a new direction for Catholicism in this period, locating genuine Catholic identity in the ongoing task of discerning and responding to the subtle presence of God within the means and structures of ordinary human life.

\section{Bibliography:}

1. Balthasar, Erich Przywara, in Tendenzen zur Theologie im 20. Jahrhundert. Eine Geschichte in Porträts (Stuttgart: Olten, 1966).

75 Both Newman and Przywara are often cited as influences upon Vatican II. Pope Paul VI famously declared the Second Vatican Council to be "Newman's Council." See Cornwell, An Unquiet Grave, 237. Przywara's influence, while less explicit, is nonetheless evident in the significance attributed to his work by later theologians such as Rahner and Balthasar, as well as Joseph Ratzinger (Benedict XVI). See Przywara, Analogia Entis, 6-7. 
2. Biemer G., Theodor Haecker: In the Footsteps of John Henry Newman, New Blackfriars 81 (2000).

3. Burrell D., Newman in Retrospect, in The Cambridge Companion to John Henry Newman.

4. Chadwick O., Newman: A Short Introduction (New York: Oxford Univ. Press, 2010).

5. Connolly J. R., Newman's Vision of Holiness in This World, in Newman Ë Life in the Spirit, ed. J. R. Connolly and B. W. Hughes (Minneapolis: Fortress Press, 2014).

6. Connolly J. R., The Indwelling of the Holy Spirit and D. Nussberger, Marked by Christ's Presence: Newman's Incarnational Spirituality, in Newman $\mathcal{E}$ Life in the Spirit, ed. J. R. Connolly and B. W. Hughes (Minneapolis: Fortress Press, 2014).

7. Cornwell J., Newman's Unquiet Grave (London: Continuum, 2010).

8. Daly G., Newman, Divine Revelation, and the Catholic Modernists, in Newman and the Word, ed. T. Merrigan and I. T. Ker (Paris: Peeters, 2000).

9. Daly G., Transcendence and Immanence: A Study in Catholic Modernism and Integralism (Oxford: Clarendon Press, 1980).

10. George Tyrell and Catholic Modernism, ed. O. P. Rafferty (Portland, OR: Four Courts Press, 2010).

11. Gerl-Falkovitz H.-B., 'His Whole Life Consisted of a Search for Religious Truth': Edith Stein in Conversation with John Henry Newman, in Contemplating Edith Stein, ed. J. A. Berkman (Notre Dame, IN: Univ. of Notre Dame Press, 2006).

12. Gilley S., Life and Writings, in The Cambridge Companion to John Henry Newman (New York: Cambridge Univ. Press, 2009).

13. Gilley S., Newman and His Age (London: Darton, Longman, and Todd, 1990).

14. Hughes G., Conscience, in The Cambridge Companion to John Henry Newman.

15. Johnson, K. L. Karl Barth and the Analogia Entis (New York: T\&T Clark, 2010).

16. Ker I., Newman on the 'Consensus Fidelium' as 'The Voice of the Infallible Church', in Newman and Word.

17. Livingston J. C., Modern Christian Thought, vol. 1: The Enlightenment and the Nineteenth Century (Minneapolis: Fortress Press, 2006).

18. Livingston J. C., Schüssler Fiorenza F. et al., Modern Christian Thought, vol. 2: The Twentieth Century (Minneapolis: Fortress Press, 2000).

19. Misner P., The 'Liberal' Legacy of Newman, in Newman and the Modernists, ed. M. J. Weaver (New York: Lantham, 1985).

20. Mongrain K., Newman and the Spirituality of the Oratory, in Newman 8 Life in the Spirit.

21. Neufeld K., Kategorien des Katholischen. P. Erich Przywara - 100 Jahre, in Catholica 43, no. 2 (1989).

22. Newman J. H., An Essay in Aid of a Grammar of Assent (London: Longmans, 1903).

23. Newman J. H., Christentum. Ein Aufbau, 8 vols., trans. O. Karrer (Freiburg: Herder, 1922).

24. Newman J. H., Discourses to Mixed Congregations (London: Longmans, 1906).

25. Newman J. H., Fifteen Sermons Preached Before the University of Oxford (London: Longmans, 1898).

26. Newman J. H., Grammar of Assent. 
27. Newman J. H., Meditations and Devotions of the Late Cardinal Newman (New York: Longmans, Green, 1893).

28. Newman J. H., Newman the Oratorian: Oratory Papers (1846-1878), ed. P. Murray (Herefordshire, UK: Gracewing, 2004).

29. Newman J. H., Parochial and Plain Sermons, vol. 4 (London: Longmans, 1909).

30. Newman J. H., The Heart of Newman (San Francisco: Ignatius Press, 1997).

31. O'Meara T. F., Erich Przywara, S.J.: His Theology and His World (Notre Dame, IN: Univ. of Notre Dame Press, 2002).

32. Pierce A., Crossbows, Bludgeons and Long-range Rifles: Tyrell, Newman, and 'The Intimate Connection between Methods and their Results', in George Tyrell and Catholic Modernism.

33. Przywara E., Analogia Entis: Metaphysics: Original Structure and Universal Rhythm, trans. J. R. Betz and D. B. Hart (Grand Rapids, MI: Eerdmans, 2014).

34. Przywara E., Gottgeheimnis Der Welt: Drei Vorträge über die Geistige Krisis der Gegenwart, in Schriften, vol. 2 (Eisiedeln: Johannes-Verlag, 1962).

35. Przywara E., Konvertiten, in Ringen der Gegenwart: gesammelte Aufsätze 1922-27, vol. 1 (Augsburg: B. Filser-Verlag), 1929).

36. Przywara E., Polarity: A German Catholic's Interpretation of Religion, trans. A.C. Bouquet (London: Oxford Univ. Press, 1935).

37. Przywara E., St. Augustine and the Modern World, trans. E. I. Watkin, in St. Augustine: His Age, Life, and Thought (New York: Meridian Books, 1964).

38. Przywara E., Zum Newmanschen Denktypus, in Jahrbuch des Verbandes der Vereine katholischer Akademiker zur Pflege der katholischer Weltanschaunng (Augsburg: Verband der Vereine katholischer Akademiker, 1922).

39. Przywara E., Zur Geschichte des Modernistischen Newman, Stimmen der Zeit 102 (1922).

40. Przywara E., Zur Geschichte des 'modernistischen' Newman, Stimmen der Zeit 102 (1922).

41. Rahner K., Gnade als Freiheit. Kleine theologische Beiträge (Freiburg: Herder, 1968).

42. Sheridan T. L., Justification, in The Cambridge Companion to John Henry Newmanin Newman $\mathcal{E}$ Life in the Spirit, ed. J. R. Connolly and B. W. Hughes (Minneapolis: Fortress Press, 2014).

43. Wulf F., Christliches Denken. Eine Einführung in das theologische-religiöse Werk von Erich Przywara, S.J. (1889-1972), in Gottes Nähe, ed. P. Imhof (Würzburg: Echter, 1990).

44. Zeitz J. V., Erich Przywara: Visionary Theologian, Thought 58 (1983). 